\title{
Introduction \\ Introduction: severe sepsis and drotrecogin alfa (activated)
} Antonio Artigas ${ }^{1}$ and Claude D Martin ${ }^{2}$

\author{
${ }^{1}$ Critical Care Center, Sabadell Hospital, CIBER Enfermedades Respiratorias, Parc Tauli University Institute, Parc Tauli, 08208 Sabadell, Spain \\ ${ }^{2}$ Anesthesia and Intensive Care Department and Trauma Center, Nord University Hospital, boulevard Pierre Dramard, 13915 Marseille Cedex 20, France
}

Corresponding author: Antonio Artigas, aartigas@tauli.cat

Published: 19 December 2007

This article is online at http://ccforum.com/content/11/S5/S1

(c) 2007 BioMed Central Ltd

Despite continuing advances in intensive care medicine, severe sepsis and septic shock are currently among the most common causes of morbidity and mortality in intensive care. Moreover, the incidence of severe sepsis and septic shock has increased with ageing of the population over the past decade [1-3]. The Surviving Sepsis Campaign advocates early identification and intervention worldwide to improve overall management of sepsis and to reduce sepsis-related death $[4,5]$.

Clinical trials conducted over more than half a century aimed at reducing the high acute morbidity and mortality rates associated with severe sepsis have shown that recombinant human activated protein C (rhAPC), or drotrecogin alfa (activated), is a treatment that reduces the overall mortality rate in patients with severe sepsis. However, this knowledge has been slow to spread, in part because of the complexity and heterogeneity of this condition, but also because rhAPC treatment is not without risks. Nevertheless, rhAPC is clearly a life-saving treatment, and the reduction in mortality far outweighs the risks involved.

As outlined by the US Food and Drug Administration, rhAPC should be considered for patients with severe sepsis resulting in multiple organ failure who are at low risk for bleeding complications and high risk for death, as indicated by initial Acute Physiology and Chronic Health Evaluation or other measurement. Determining who to treat with rhAPC may be the biggest problem facing intensive care physicians.

Since the publication of the positive results from the PROWESS (Recombinant Human Activated Protein C Worldwide Evaluation in Severe Sepsis) trial, research into the protein $\mathrm{C}$ pathway has expanded significantly and additional clinical information about the uses of rhAPC and its specific activity have been reported. In this supplement to Critical Care, leading experts describe new insights into the role of the protein $\mathrm{C}$ pathway, along with clinical use of rhAPC and its results.
Critical Care 2007, 11(Suppl 5):S1 (doi:10.1186/cc6180)

The supplement begins with an article by Claessens and Dhainaut [6]. They review the main proposals of the Surviving Sepsis Campaign and focus on the difficulties in reaching the correct diagnosis and in providing appropriate treatment to septic patients at the right time.

The next two articles focus on the protein $\mathrm{C}$ pathway and its clinical relevance. Levi and van der Poll [7] analyze the various mechanisms of action of rhAPC in sepsis. Given the central role played by inadequate functioning of the protein $\mathrm{C}$ pathway in the pathogenesis of sepsis, restoring the function of this pathway in patients with sepsis appears to be a rational approach; the beneficial effects of rhAPC in experimental sepsis models and clinical studies seem to support this. Although the relative importance of the anticoagulant relative to the inflammation-modulating effects is unclear, it is tempting to hypothesize that a combined effect is responsible for the benefits derived from rhAPC. Recent studies also suggest that rhAPC has direct antiinflammatory properties brought about by its binding to neutrophils and decreasing chemotaxis [8]. In addition, recent in vitro studies have shown that rhAPC can modulate the endothelium by binding to various receptors that are important for endothelial cell integrity [9].

Vangerow and coworkers [10] describe the predictive value of plasma protein $\mathrm{C}$ levels in sepsis. They also describe the usefulness of this biomarker for identifying those patients with severe sepsis who are most likely to benefit from rhAPC and for helping the clinician to measure the response to rhAPC. This hypothesis is currently being tested in RESPOND (Research Evaluation Serial Protein C levels in severe sepsis patients On Drotrecogin alfa [activated]) a worldwide phase II study.

The supplement concludes with three practical clinical articles. In the first of these, Laterre [11] reviews all large clinical trials of rhAPC. Continued safety assessment is

rhAPC $=$ recombinant human activated protein $\mathrm{C}$. 
essential for any newly approved therapy; in the next article, Fumagalli and Mignini [12] review the safety profile of rhAPC in all published studies, which altogether include approximately 8,000 patients. Using a uniform definition of serious bleeding to analyze the findings of the various studies, they demonstrate a consistent rate of serious bleeding of $2.4 \%$ but conclude that this adverse effect is outweighed by the drug's benefits in patients with severe sepsis who are at high risk for death. In the final article, Camporota and Wyncoll [13] define the patients who are most likely to benefit from rhAPC and describe when to start and how to manage infusion to ensure effective treatment while minimizing the risk for bleeding.

We hope that this supplement will provide readers with an up-to-date summary of the protein $\mathrm{C}$ pathway from bench to bedside, along with practical guidelines for the early identification of the patients who will benefit from rhAPC and general recommendations for the appropriate use of rhAPC in severe sepsis.

We thank all of the authors for their valuable contributions toward clarifying the controversy about the efficacy and use of rhAPC in critically ill patients with severe sepsis. Given the advances made in sepsis care and various scientific questions surrounding the drug, this is an opportune time to gather additional clinical evidence on the efficacy, safety and the benefit-to-risk relationship accompanying rhAPC use and initiate the new, often requested, phase III placebo-controlled study PROWESS-SHOCK, scheduled to begin in 2008.

\section{Competing interests}

AA has received reimbursements as a member of the European Advisory Committee of Eli Lilly and Company. AA has not received any funding from Eli Lilly and Company for the preparation of this article. CM declares that he has no competing interests.

\section{Acknowledgement}

This article is part of Critical Care Volume 11 Supplement 5: Severe sepsis and drotrecogin alfa (activated). The full contents of the supplement are available online at http://ccforum.com/supplements/11/S5. Publication of the supplement has been sponsored by Eli Lilly and Company.

\section{References}

1. Angus DC, Linde-Zwirble WT, Lidicker J, Clermont G, Carcillo J, Pinsky MR: Epidemiology of severe sepsis in the United States: analysis of incidence, outcome and associated costs of care. Crit Care Med 2001, 29:1303-1310.

2. Martin GS, Mennino DM, Eaton S, Moss M: The epidemiology of sepsis in the United States from 1979 through 2000. N Engl J Med 2003, 348:1546-1554.

3. Alberti C, Brun-Buisson C, Burchardi H, Martin C, Goodman S, Artigas A, Sicignano A, Palazzo M, Moreno R, Boulmé R, Lepage $\mathrm{E}$, et al:: Epidemiology of sepsis and infection in ICU patients from an international multicentre cohort study. Intensive Care Med 2002, 28:108-121.

4. Rivers E, Nguyen B, Havstad S, Ressler J, Muzzin A, Knoblich B, Perterson E, Tomlanovich M; Early Goal-Directed Therapy Collaborative Group: Early goal directed therapy in the treatment of severe sepsis and septic shock. N Engl J Med 2001, 345: 1368-1377.
5. Dellinger RP, Carlet JM, Masur H, Gerlach H, Calandra T, Cohen J, Gea-Banacloche J, Keh D, Marshall JC, Parker MM, et al.; Surviving Sepsis Campaign Management Guidelines Committee: Surviving Sepsis Campaign guidelines for management of severe sepsis and septic shock. Crit Care Med 2004, 32:858873.

6. Claessens Y-E, Dhainaut J-F: Diagnosis and treatment of severe sepsis. Crit Care 2007, 11(suppl 5):S2.

7. Levi M, van der Poll T: Recombinant human activated protein C: current insights into its mechanism of action. Crit Care 2007, 11(suppl 5):S3.

8. Nick JA, Coldren C, Geraci MW, Poch KR, Fouty BW, O'Brien J, Gruber M, Zarini S, Murphy RC, Kuhn K, et al:: Recombinant human activated protein $C$ reduces human endotoxin-induced pulmonary inflammation via inhibition of neutrophil chemotaxis. Blood 2004, 104:3878-3885.

9. Feistritzer C, Riewald M: Endothelial barrier protection by activated protein $C$ through PAR-1 dependent sphingosine-1phosphate receptor-1 crosses activation. Blood 2005, 105: 3178-3184.

10. Vangerow B, Shorr AF, Wyncoll D, Janes J, Nelson DR, Reinhart $\mathrm{K}$ : The protein $\mathrm{C}$ pathway: implications for the design of the RESPOND study. Crit Care 2007, 11(suppl 5):S4.

11. Laterre P-F: Clinical trials in severe sepsis with drotrecogin alfa (activated). Crit Care 2007, 11(suppl 5):S5

12. Fumagalli R, Mignini MA: The safety profile of drotrecogin alfa (activated). Crit Care 2007, 11(suppl 5):S6.

13. Camporota L, Wyncoll D: Practical aspects of treatment with drotrecogin alfa (activated). Crit Care 2007, 11(suppl 5):S7. 